\title{
Research on Trading Friction between China and the US from Game Theory Perspective
}

\author{
Zhenchuan Jiang1, Xun Gong2,3,4*, Hongping Cheng2 \\ ${ }^{1}$ Graduate School of Lyceum of the Philippines University, Manila, Philippines \\ ${ }^{2}$ Center of Health Administration and Development Studies, Hubei University of Medicine, Shiyan, China \\ ${ }^{3}$ School of Medicine and Health Management, Tongji Medical College, Huazhong University of Science and Technology, Wuhan, \\ China \\ ${ }^{4}$ School of Economics and Management, Beijing Jiaotong University, Beijing, China \\ Email: jiangzc0810@163.com, *gongxun83@aliyun.com
}

How to cite this paper: Jiang, Z.C., Gong, X. and Cheng, H.P. (2020) Research on Trading Friction between China and the US from Game Theory Perspective. American Journal of Industrial and Business Management, 10, 19-29.

https://doi.org/10.4236/ajibm.2020.101002

Received: November 12, 2019

Accepted: December 31, 2019

Published: January 3, 2020

Copyright $\odot 2020$ by author(s) and Scientific Research Publishing Inc. This work is licensed under the Creative Commons Attribution International License (CC BY 4.0).

http://creativecommons.org/licenses/by/4.0/

\begin{abstract}
Since the development of free trade theory, global economy has developed extremely rapidly. However, protectionism has played a negative role in free trade. It is widely known that the trade friction between China and the US has attracted attention by the whole world and the result may influence the global economy. This paper will analyze the trade friction from game theory, how China and the US can gain optimal payoff and which kind of strategy will be used by China and the US.
\end{abstract}

\section{Keywords}

The US, China, Trade Friction, Surplus, Deficit, Imposing Tariffs, Protectionism, Game Theory Model

\section{Introduction}

Because of the development of international business, the integration and globalization of the world economy are increasingly tight. Citizens from Iceland can have coconut from the Philippines. From 1800 to 2008, the volume of global exports has increased over 2296 times [1]. However, due to imbalance of productivities or nature resource, trade deficit has generated. In order to return the deficit, some industries require to be protected and supported by the government to gain competitive advantages from global competitors. Therefore, trading friction has been more and more sharply. Because of the 2008 financial crisis, the global economy has suffered tremendously. As a result, the increasing number of trade friction has generated by protectionism. As the biggest export coun- 
try, China achieves export value at $\$ 2655.61$ trillion [2] and gains huge loss because of trade protectionism. Recently, trading friction between China and the US has attracted attention from billions of people. The US government wants to impose billions of dollars tariff on China's export [3]. From August 2017, the US government wants to impose billions of dollars tariff on China's export [4]. The unfairness cannot be accepted by Chinese government and industries.

From economic perspective, if the trade friction cannot be solved in an effective way, both China and the US would suffer so much loss so that the global economy would be a serious decline. Therefore, negotiation is taking place on the trading war to achieve more benefits for both two countries. Both the two countries have their best payoffs, but can they achieve own targets at the same time, or how they can gain optimal payoffs under the sharp friction. The object of this paper is to analyze the effects of trading friction by game theory, the Chicken Game Model will be involved to present the strategies and payoffs from the two countries. It may be helpful for individuals and organizations under this economy event.

\section{Literature Review}

\subsection{Fact of International Trade and Protectionism}

Since $18^{\text {th }}$ century, the importance of free trade has been realized by economists. Adam Smith issues absolute advantage theory to encourages a nation to produce more effective items and free trade to others. The invisible hand has ability to adjust economy to make both countries achieve benefits [5]. Based on Smith, David Ricardo and other economists develop free trade theory. It can be concluded that one country should concentrate domestic resource to produce the most effective production to export for benefits, and import the goods which this country has less capacity. Therefore, free trade has academic support to develop. In addition, due to Vernon's product life-cycle theory, which can be presented that in order to reduce costs, production location changes from developed counties to developing countries [5]. With the development of international trade, international division and global value chains are generated. Advanced companies from developed countries can select good location to produce more efficiently [6]. The fact of recent international trade is that multinational corporation invests to developing countries, especially, in manufacturing, due to lower cost, particularly cheap labor force. The fact is that developing countries are regarded as manufacturing platform of developed countries [7]. For instance, Apple's products are manufactured in China, but only $2 \%$ - 3\% profit of the total value can be disputed to Chinese manufacturing firms [6] [7].

On another hand, international trade is regarded as a positive-sum game, but every country requires to achieve more benefits from global trade and help domestic industries gain more profits from international competitors [5]. Therefore, trade protectionism is generated. Trade protection is defined as "trade protection is the deliberate attempt to limit imports or promote exports by putting 
up barriers to trade. Despite the arguments in favor of free trade and increasing trade openness, protectionism is still widely practiced [8]". It is widely believed that trade friction is the product of protectionism, which is a revenge from other countries. It is presented that "trade friction represents the natural state of international economic affairs. While the benefits of free trade are unassailable, from time to time, distributional impacts to distribution caused by comparative advantage move to the forefront of economic diplomacy [9]".

It is shown that, motives for protection including protecting sunrise industries, sunset industries, strategic industries, non-renewable resources and save employments [10]. In addition, tariffs, import quotas, product standards, and government subsidies are common method to protect domestic industries [11].

\subsection{The History of Trade Friction between China and the US}

It can be presented that the history of trade friction between China and the U.S can be divided into 2 stages, at the point financial crisis in 2008. Before 2008, there are 4 characters trade friction between China and the U.S, firstly, it occurs frequently (almost two years) and has a short duration (each duration is about one year); the second is only for specific industries; the third is usually initiated by industry associations, and then by the government; the fourth is that the trade frictions between the two sides are terminated by negotiating bilateral agreements or consensus. After 2008, the trade protection initiated by the U.S against China has spread from a single industry to multiple industries, and the protection of traditional industries has gradually shifted to the protection of strategic emerging industries. At the same time, trade protection measures have become more diverse and deepened into the intervention of foreign exchange rates [12].

However, this time, the sharp friction may lead to a serious trade war. Since Trump is in power, the friction has been updated. Trump's signing of the launch of the "special 301 report" directly led to the US tens of billions of dollars in tariff penalties for China. Moreover, Trump publicly stated that China is a competitor, which greatly improved the possibility of trade war [13]. At $15^{\text {th }}$ August 2019, the trade friction between China and the US has continued over 400 days, the negotiations have no crucial progress, the US insists on tariffs applied exclusively to Chinese goods: US $\$ 250$ billion, and threatens tariffs on US $\$ 325$ billion more. As a response, China presents total tariffs applied exclusively to US goods: US\$110 billion [3].

\subsection{The Core Issue of Trade Friction between China and the US}

On the one hand, the statistics from China Customs show that in 2018, bilateral trade between China and the U.S totaled US\$633.52 billion, an increase of $8.5 \%$ year-on-year, accounting for $13.7 \%$ of China's total trade, during the same period. Among them, China's exports to the U.S are US $\$ 478.42$ billion, increasing $11.3 \%$ year-on-year, accounting for $19.2 \%$ of China's total exports of goods; imports from US are US $\$ 155.10$ billion, up $0.7 \%$, accounting for $7.3 \%$ of China's 
total imports. China has a surplus almost 323.33 billion U.S. dollars, climbing up $17.2 \%$ [14]. The US is China's second largest trading partner, the largest export market and the sixth largest source of imports. According to the statistics of the US Department of Commerce, the total Sino-US trade in 2018 is US $\$ 659.85$ billion, an increase of $3.9 \%$. Among them, the U.S exported 120.34 billion US dollars to China, decreasing 7.4\%, accounting for $7.2 \%$ of total US exports; the U.S imported 539.50 billion US dollars from China, climbing 6.7\%, accounting for $21.2 \%$ of total US imports [14]. Despite the different statistics, China still has a trade surplus of more than 300 billion US dollars. The Trump's administration has strong willing to narrow, even eliminate the gap. In addition, imposing tariffs can help to increase domestic employment.

On another hand, the "China Manufacturing 2025" strategy has been implemented smoothly, China is attempting to grow to a strong manufacturing nation [15]. This is due to the fact that China plans to update its industrial structure from low value add to high value add. Transforming from labor-intensive economy to high-tech-oriented economy [16] [17]. With the accumulation of capital and update of development strategy, increasing Chinese companies pay more attention to innovation and first mover, and high-tech industry develops rapidly, which means that China's high-tech firms such as Huawei play increasing role in global business. Since 2010, China has been the second position in the whole world GDP ranking, but the Gap between China and the U.S is extremely huge. At the end of 2018, GDP of the U.S is $\$ 20,494$ billion, meanwhile, China's GDP is $\$ 13,608$ billion. The data of the U.S is almost the sum of China, Japan and Germany [18]. China is still a manufacturing platform of labor-intensive products for the US. However, some politicians believe that the US is falling down the Thucydides's trap, which can be defined as a strong emerging power will inevitably challenge the existing dominant power, and the existing dominant power will inevitably respond to such threats by various methods. The Thucydides trap concept is widely used and is almost regarded as the "inexorable rule" of international relations [19]. In addition, Zhang (2018) presents that in modern civilization, the direct military conflict between the China and the US is irrational [20]. Therefore, economic sanctions and even trade frictions are expected methods to this issue. In addition, since the Second World War, the three pillars of US dollar, American values, and military power that American hegemony relied on have been relaxed as never before, indicating that the United States is declining. Meanwhile, China's reform and opening up has continued to deepen, and supply-side structural reforms have achieved remarkable results, helping China's economy move toward high-quality development [21]. The ongoing trade friction between China and the United States is closely related to the US government's confrontation policy or even hostility to China. The current policy of the US is based on the misunderstanding of the US government toward China [4]. The US administration has strong willing to limit China's development. 


\subsection{The Theorical Connections between Trade Friction and Game Theory}

Game theory is about decision-making choices and decision-making equilibrium problems when the behaviors of various decision-making bodies interact [22]. According to game theory, games can be classified into zero-sum or non-zero-sum, cooperative or non-cooperative, symmetric or asymmetric, simultaneous or sequential and perfect information or imperfect information. In addition, game theory is mainly used for trade policy analysis [23]. As a mathematical tool for policy makers, the importance of game theory lies in its approach to the design and analysis of strategic decision problems [24]. The target of international trade is for positive-sum game, win-win is the top one rule for participants. If a country that participates in trade always feels losses and the other country benefit, then the trade process will be difficult to develop healthily and sustainably. From the surplus, deficit seems like a zero-sum game of international trade. China's huge surplus means a huge deficit in the United States [22]. Therefore, Trump's administration disagrees with the trade structure with China. In addition, the win-win situation of economic justice refers to the subjective feeling in the sense of value judgment. If trade is not forced by the outside world and the two sides of the trade are willing to act, it can be believed that trade is fair and beneficial to both sides. The two sides of the trade have achieved such a result: they have obtained what they want on a voluntary basis and have improved their own interests. A key goal of game theory is to achieve the optimal strategy of each participant so that it can maximize its payoffs [22]. Therefore, the US government desires to optimize its benefits and provokes trade disputes. China has enough reasons to reject these peremptory demands of the US. This is the theorical supporting for the trade friction.

\section{Methodology}

\subsection{Research Design}

Qualitative research will be used in this paper, and a dynamic game model will be designed including China and the US Game theory is a useful research method to analyze the issues about economic and social development [25].

The Sino-US trade friction is mainly a game between China and the United States. The strategies that the two countries can choose and the final result of the game are similar to the Chicken Game model. Therefore, the Chicken Game can be used to analyze the Sino-US trade friction. The Chicken Game which is also called the cowardly game, the original intention is that two cocks meet, there are four kinds of situations: two loses, loses each other and one of them retreats. The outcome of the two defeats is obviously irrational, and if one wants to retreat, it will be compensated accordingly. However, in this case, the Chicken Game needs to be updated slightly because the game is not equilibrium.

In the case of trade friction, there are 4 results generated by strategies of China and the US, which are shown in Chart 1. 
Chart 1. Basic result of China and the U.S action [13].

\begin{tabular}{cccc}
\hline China & US & tough & compromise \\
\hline Tough & $\mathrm{A}$ & $\mathrm{C}$ \\
compromise & $\mathrm{B}$ & $\mathrm{D}$ \\
\hline
\end{tabular}

1) The U.S act strongly, China counterattack mighty, tit-for-tat.

2) The U.S act strongly, China is forced to compromise.

3) Because of China's force, the US stop trade friction.

4) After effective and friendly negotiation, China and the U.S have a new deal.

According to historical experience and current situation, mentioned in former sector, neither China nor US wants to bear the huge loss. Therefore, China and the U.S are basically impossible to be tit-for-tat, the possibility of result B is limited. Therefore, a cooperative game is hypothesized. Refer to the fact, the U.S acts firstly and China responses to it, so, this game is asymmetry. Due to the fact that China and the US have different optimal payoffs, they have various strategies in B, C, and D. One country's strategy will be influenced by another, so, the game is possible to be dynamic.

It can be concluded that the game of friction between China and the U.S is asymmetry, cooperative and dynamic but not equilibrium. Therefore, the payoffs from different perspectives are not the same [13]. Based on game theory and the author's hypothsis, strageties and payoffs will be presented by US perspective and China perspective.

\subsection{Game from the US Perspective}

Because of the huge trade deficits, the U.S administration believes that China has more benefits than the US, if the trade structure continues. Therefore, the author hypothesizes before the trade friction, China has 6 payoff and the US has 4 . With the strong willing of the government filling the deficits, results B and D are more possible to be accepted by the US. Compared D, for the US, B has more benefits, because more demands will be compromised by China, the U.S will gain more benefits. The author hypothesizes result $B$ with the minimum payoff $(4,6)$, in contrast, minimum result $\mathrm{D}$ presenting $(5,5)$. For result $\mathrm{A}$, both China and the US suffer huge loss, with payoff $(-1,0)$, because China has remarkable surplus, which means more loss. For result $C$, if the US gives trade friction up, the payoffs will keep on $(6,4)$. Therefore, $\mathrm{A}$ and $\mathrm{C}$ are difficult to be accepted (Chart 2).

\subsection{Game from China's Perspective}

China believes that Sino-US trade is based on mutual benefit, fair and voluntary with a win-win model. The US is the most powerful country and initiatively provokes trade friction. China is weaker to passively response and won not impose on the US. Therefore, it can be hypothesized that before the trade friction, two countries have payoffs at $(5,5)$, if the US give up trade protection, the payoff 
Chart 2. Game from the US perspective.

\begin{tabular}{cccc}
\hline China & US & tough & compromise \\
\hline Tough & $\mathrm{A}(-1,0)$ & $\mathrm{C}(6,4)$ \\
compromise & $\mathrm{B}(\leq 4, \geq 6)$ & $\mathrm{D}(\leq 5, \geq 5)$
\end{tabular}

can stay at $(5,5)$, result $C$, which is the best choice for China. If a friendly and effective negotiation can be adopted by both China and the US, China may give up some benefits within a reasonable range, accepting the result $\mathrm{D}(4,6)$. In contrast, China has little possibility to accept A, which means China may lose the biggest export market. In addition, if China compromise easily under the US's force, China may fall in a big trap and loss a great number of benefits (B) (Chart 3).

\section{Analysis of Results}

According to the different payoff matrix designed in former sector, the author will analyze the strategies from the US perspective and China perspective, respectively.

Compared with results from China and the US game strategy, result A can be abandoned, because A is the worst payoff for both two countries.

\subsection{The Possibilities of Strategy of the US}

The strategic possibilities of the U.S ranked from large to small are B, D, and C. The Trump administration imposing heavy tariffs to a great list of Chinese goods exported to the United States, the impact is not limited to Chinese export enterprises, but also directly harm some enterprises and consumers in the United States. Sino-US trade structure is that the Chinese and American goods are highly complementary. Due to the comparative advantages, China's labor-intensive products are cheap and popular in the U.S, which means that imposing tariffs on Chinese related products will cause the higher production costs and lower profits for related domestic manufacturers and the U.S consumers will also face the risk of increased consumer spending.

Furthermore, the constraints from the US society are quite obvious. On the day of the US negotiating team's set out to China, 1100 economists from the United States sent a letter to Trump to express their firm opposition to Trump's trade protection [22]. It can be seen that this US-initiated trade conflict is also unpopular inside the country.

Moreover, a great number of American companies do not want to leave Chinese market [4]. Over 1000 American companies are operating in China, by the end of 2018, the number of US investment projects in China has reached 70,181, with an actual investment of $\$ 85.19$ billion [14]. Leaving China means to abandon a huge market with the largest population and increase a great amount of costs. 
Chart 3. Game from China perspective (author's hypothetical design).

\begin{tabular}{cccc}
\hline China & US & tough & compromise \\
\hline Tough & $\mathrm{A}(0,0)$ & $\mathrm{C}(5,5)$ \\
compromise & $\mathrm{B}(\leq 3, \geq 7)$ & $\mathrm{D}(4,6)$ \\
\hline
\end{tabular}

Nevertheless, another reason for trade friction is to help to save even increase employment with some failure experience. For instance, in 2012, the President Obama imposes tariffs on Chinese tier product to increase related employments. he trade protection increases almost 1200 jobs for American with an unbelievable cost over $\$ 1.1$ billion, it means that every job cost at least $\$ 900,000$, much higher than general cost [26]. As Americans spend more in the tire industry, the market for other retail goods has been hit by nearly $\$ 1$ billion, resulting in an estimated loss of nearly 4000 jobs [27].

In summary, due to the trade situation, domestic exception and historical experience, the US has the largest possibility to choose strategy D.

\subsection{The Possibilities of Strategy of China}

By contrast, the strategic possibilities of China ranked from large to small are C, $\mathrm{D}$ and $\mathrm{B}$. Because of asymmetric, perfect information and dynamic game for China, China is weaker and knows the U.S actions and willing. However, the Chinese administration has announced officially that China absolutely not afraid to a trade war and accept friendly and effective negotiation to fix friction, which means that China's strategy focuses on result D, when the US is compromise and China negotiates with it.

In addition, in the US trade protection is always driven by interest groups, which means various group has different requirements [28]. For instance, textile industry reports to the administration to impose tariffs on Chinese products, as a counterattack, China can impose tariffs on American's agricultural products. It is possible for agricultural industry in the US to push to abandon the tariffs on Chinese textile products.

Furthermore, the Trump administration has imposed tariffs on European Union (EU), Japan, Mexico and other economies, besides China [29]. The U.S actions are harmful to the global economic structure [30]. It is widely known that countries of the world play a comparative advantage and cooperate with each other to form a global industrial chain, supply chain and value chain that operate efficiently. The US actually increases taxes on all companies in the chain, forcing entrepreneurs to reduce investment, and the economic growth momentum is weakened. If the trade war between China and the US breaks out, the global economy will be destroyed seriously, because of the fierce conflict between the top two powerful economies.

Nevertheless, up to June, 2019, China still holds $\$ 1,112,500$ billion the US Treasuries [31]. As the biggest creditor country of the US, China plays a crucial role to maintaining stability in the US financial market. 
In summary, if the US acts tough, China will be tough, but the best choice is that both two countries are compromise.

\section{Conclusion and Recommendation}

To sum up, the US is stronger than China, but it has many limitations from both domestic and outside. Although China is the weaker one, both China government and Chinese have confidence and courage to face the trade war. China and the United States are most likely to be compromise and negotiate to achieve maximum profitability within the acceptable range of both parties. This is the optimal payoff of the game.

As the global economic competition becomes increasingly fierce, China may face more trade frictions. In order to effectively deal with the unknown threats, China should do the appropriate preparations and plan ahead. For developing countries like China, it is necessary to develop multilateral trade, and strengthen economic and trade cooperation globally; expand domestic demand and activate domestic market; develop high-tech and accelerate upgrading industrial structure, to take an active position in international trade.

The game of powerful countries is complex and will be affected by a lot of factors. Some constant variables cannot be shown by basic game theory model.

\section{Funding}

This paper supported by Key Research Center for Humanities and Social Sciences in Hubei Province (Hubei University of Medicine) (2019YB007) and youth program of high end science and technology innovation think tank of China Association of science and technology (DXB-ZKQN-2017-043).

\section{Conflicts of Interest}

The authors declare no conflicts of interest regarding the publication of this paper.

\section{References}

[1] Esteban, O., Beltekian, D. and Roser, M. (2014) Trade and Globalization, Our World in Data. https://ourworldindata.org/trade-and-globalization

[2] The World Bank (2019) Exports of Goods and Services. https://data.worldbank.org/indicator/NE.EXP.GNFS.CD?most_recent_value_desc=t rue

[3] Shira, D. (2019) The US-China Trade War: A Timeline. China Briefing. https://www.china-briefing.com/news/the-us-china-trade-war-a-timeline

[4] Wen, W. (2019) Time Is on China's Side in Trade Talks with US. Global Times Business.

https://go.gale.com/ps/retrieve.do?tabID=T003\&resultListType=RESULT_LIST\&searchR esultsType $=$ SingleTab\&search Type $=$ BasicSearchForm\&currentPosition $=1 \& \mathrm{docId}=$ GALE\%7CA594858228\&docType=Article\&sort=Relevance\&contentSegment $=$ ZNE W-FullText\&prodId=GPS\&contentSet=GALE\%7CA594858228\&searchId=R4\&user GroupName=lyceumph\&inPS=true 
[5] Hill, C.W.L. (2000) International Business. McGraw-Hill, New York, 55-300.

[6] Dedrick, J., Kraemer, K. and Greg, L. (2008) Who Profits from Innovation in Global Value Chains? A Study of the iPod and Notebook PCs. Sloan Industry Studies Annual Conference, Boston, (5) 1-2, 2-10. https://doi.org/10.2139/ssrn.1125024

[7] Xing, Y. (2012) The People's Republic of China's High-Tech Exports: Myth and Reality. ADBI Working Paper 357, Asian Development Bank Institute, Tokyo. http://www.adbi.org/working-paper/2012/04/25/5055.prc.high.tech.exports.myth.reality https://doi.org/10.2139/ssrn.2052778

[8] Economic Online. https://www.economicsonline.co.uk/Global_economics/Trade_protectionism.html

[9] Bruseulas, J. (2018) Trade Friction: A Primer on the United States and China. https://www.globalbankingandfinance.com/trade-friction-a-primer-on-the-united-s tates-and-china

[10] Maggi, G. and Rodriguez-Clare, A. (2000) Import Penetration and the Politics of Trade Protection. Journal of International Economics, 51, 287-304. https://doi.org/10.1016/S0022-1996(99)00029-X

[11] Goldberg, P.K. and Pavcnik, N. (2016) The Effects of Trade Policy. In: Handbook of Commercial Policy, Volume 1, Part A, Elsevier, Amsterdam, 161-206. https://doi.org/10.1016/bs.hescop.2016.04.002

[12] Moore, M.O. (2017) Carbon Safeguard? Managing the Friction between Trade Rules and Climate Policy. Journal of World Trade, 51, 43-66.

[13] Liu, Y. and Pan, Y. (2019) Game Analysis of Sino-US Trade War. Journal of Economics of Shanghai School, No. 17, 20-37.

[14] MOFCOM (2019). http://www.mofcom.gov.cn/article/i/dxfw/nbgz/201905/20190502859509.shtml

[15] MIIT (2017) The Implementation of "China Manufacturing 2025”. http://www.cima.org.cn/article.asp?classid=49\&id=19240

[16] An, T.X., Fan, Y.J. and Zhang, H. (2011) An Analysis of the Model of China's Industrial Restructuring and Upgrading-Borrowing Ideas from the Experience of Japan. Energy Procedia, 5, 1461-1466. https://doi.org/10.1016/j.egypro.2011.03.250

[17] Zhang, Z. and Li, Y. (2015) Research on International R\&D Investment in the Global Innovation Value Chain. Scientific Research, No. 10, 1487-1495.

[18] World Bank (2019). https://databank.worldbank.org/data/download/GDP.pdf

[19] Cai, C.H. (2016) The “Thucydides Trap" Discourse in China-US Relations. Sociology Digest, No. 9, 13-31. (In Chinese)

[20] Zhang, K.S. (2018) Rethinking China-Us Trade Relations. Social Sciences Abroad, 5, 153-154. (In Chinese)

[21] Meng, L. and Liang, Y. (2018) The Multistage Dynamic Game Analysis on How Does Trade Dispute between China and the U.S. Leap Over the Thucydides Trap. China Business and Market, No. 32, 85-97.

[22] Jia, K. and Ou, C.Z. (2018) View on the Current Sino-US Trade Negotiations from the Perspective of Game Theory. Yicai.com. https://www.yicai.com/news/5426747.html

[23] Alexa, V. and Toma, S. (2012) The Correlation between Game Theory and International Trade. Economics and Applied Informatics, 18, 67-74.

[24] John, M. (1994) Game Theory in International Economics. Harwood Academic Publishers, Langhorne. 
[25] Jiang, Z.C. and Gong, X. (2019) Research on Issues of Budget Performance Management on the Process of Budgeting by Game Theory. Journal of Financial Risk Management, 8, 193-199. https://doi.org/10.4236/jfrm.2019.84013

[26] Hufbauer, G.C. and Lowry, S. (2012) US Tire Tariffs: Saving Few Jobs at High Cost, Peterson Institute for International Economics, Washington DC.

https://www.piie.com/publications/policy-briefs/us-tire-tariffs-saving-few-jobs-high -cost

[27] Davidson, E. (2018) Trump Can Learn from Obama's Tariff Debacle. Washington Examiner.

https://www.washingtonexaminer.com/trump-can-learn-from-obamas-tariff-debacle

[28] Ju, J.D. (2018) ABCs of Sino-US Trade Conflict. Financial Minds, No. 3, 5-13.

[29] Amadeo, K. (2019) Trade Wars and Their Effect on the Economy and You, Why Trade Wars Are Bad and Nobody Wins. The Balance.

https://www.thebalance.com/trade-wars-definition-how-it-affects-you-4159973

[30] Amaro, S. (2019) A Trade War with Europe Would Be Larger and More Damaging than Washington's Dispute with China. CNBC.

https://www.cnbc.com/2019/08/22/why-a-us-trade-war-with-europe-would-be-mor e-damaging-than-china.html

[31] CEIC (2019).

https://www.ceicdata.com/zh-hans/china/holdings-of-us-treasury-securities 